\title{
PENGARUH PERSEPSI KUALITAS DAN KEPUASAN TERHADAP LOYALITAS PELANGGAN PADA KOPERASI KREDIT (CREDIT UNION) MANDIRI CABANG MEDAN (Studi Kasus : Pelanggan Koperasi Kredit (Credit Union) Mandiri Cabang Medan)
}

\author{
Oleh : \\ Peran Simanihuruk
}

\begin{abstract}
Abtsrak
Tujuan penelitian ini menganalisis pengaruh persepsi kualitas dan kepuasan terhadap loyalitas pelanggan pada Koperasi Kredit (Credit Union) Mandiri Cabang Medan. Manfaat penelitian, memberikan bukti empiris mengenai pengaruh variabel yang dapat mempengaruhi persepsi kualitas dan loyalitas pelanggan. Jumlah sampel 96 nasabah, metode pengumpulan data melalui koesioner dan dokumentasi, metode analisis data digunakan regresi linier dan berganda dan untuk menguji hipotesis digunakan uji t dan uji F.

Hasil penelitian menunjukkan variabel harga berpengaruh signifikan terhadap persepsi kualitas, variabel reputasi perusahaan berpengaruh signifikan terhadap persepsi kualitas, variabel persepsi kualitas berpengaruh signifikan terhadap variabel loyalitas pelanggan. variabel kepuasan pelanggan berpengaruh signifikan terhadap variabel loyalitas pelanggan, variabel harga dan reputasi perusahaan mempunyai pengaruh yang positif terhadap persepsi kualitas dan variabel persepsi kualitas dan kepuasan Pelanggan mempunyai pengaruh yang positif terhadap loyalitas pelanggan.

Berdasarkan hasil penelitian, sebaiknya pihak Koperasi Kredit (Credit Union) Mandiri Cabang Medan memperhatikan variabel harga yang terkait dengan konsumen sasaran maupun pesaing, variabel reputasi perusahaan yang terkait dengan pengalaman perusahaan, kompetensi perusahaan dan keunggulan perusahaan, variabel persepsi kualitas yang terkait dengan keandalan (Reliability), ketanggapan (Responsiveness), keyakinan (Assurance), empati (Empathy) dan Tangibles. variabel kepuasan pelanggan supaya tetap dipertahankan yang terkait dengan kesesuaian harapan , persepsi kinerja dan penilaian pelanggan dan mempertahankan variabel loyalitas pelanggan yang terkait dengan Repeat Purchase, Retention dan Referalls.
\end{abstract}

Kata kunci : Persepsi Kualitas, Loyalitas Pelanggan

\section{PENDAHULUAN}

Persaingan dunia bisnis jasa pada tahun terakhir ini semakin ketat dengan adanya kemajuan teknologi komunikasi dan informasi. Semakin mudahnya mendapat informasi maka alternatif pilihan produk/jasa yang tersedia di pasar semakin mudah didapatkan. Para produsen atau penjual berusaha memenuhi kebutuhan dan keinginan serta memberikan kepuasan 
secara maksimal kepada konsumen. Kinerja pelayanan yang tinggi merupakan hal yang sangat mendasar bagi kelangsungan hidup suatu perusahaan jasa. Pelayanan yang berkinerja tinggi adalah pelayanan yang mampu memberikan kepuasan terhadap kebutuhan pelanggan atau mampu melebihi harapan pelanggan (Anderson, Fornell, dan Lehmann dalam Diana Puspitasari 2006).

Persepsi kualitas (perceived quality) merupakan persepsi pelanggan terhadap keseluruhan kualitas atau keunggulan suatu produk atau jasa layanan berkaitan dengan apa yang diharapkan oleh pelanggan. Aaker (1997) menyatakan bahwa persepsi kualitas merupakan persepsi para Pelanggan, oleh sebab itu persepsi kualitas tidak dapat ditetapkan secara obyektif. Selain itu, persepsi pelanggan akan melibatkan apa yang penting bagi pelanggan karena setiap pelanggan memiliki kepentingan yang berbeda-beda terhadap suatu produk atau jasa .

Pemenuhan harapan pelanggan yang sesuai dengan yang dipersepsikan akan menciptakan kepuasan pelanggan. Kepuasan pelanggan didefinisikan sebagai sikap berkenaan dengan barang atau jasa setelah diterima dan dipakai. Cronin dan Taylor dalam Diana Puspitasari 2006 berhasil membuktikan bahwa kepuasan pelanggan ditentukan oleh penilaian pelanggan terhadap kualitas pelayanan yang diberikan. Kepuasan pelanggan akan dipengaruhi oleh harapan, persepsi kinerja, dan penilaian atas kinerja produk atau jasa yang dikonsumsi. Oliver dalam Diana Puspitasari 2006, menyatakan bahwa kepuasan Pelanggan merupakan tingkat perasaan seseorang setelah membandingkan kinerja hasil yang dirasakannya dengan harapan.

Kepuasan Pelanggan akan menciptakan loyalitas Pelanggan untuk tetap menggunakan bisnis jasa yang ditawarkan. Loyalitas dapat diartikan sebagai suatu kesetiaan. Kesetiaan timbul tanpa adanya paksaan, tetapi timbul dari kesadaran sendiri pada masa lalu. Loyalitas Pelanggan merupakan salah satu tujuan inti yang diupayakan dalam pemasaran modern. Kepuasan Pelanggan merupakan hasil dari perbandingan antara harapan dan kenyataan yang diterima Pelanggan setelah mengkonsumsi barang atau jasa. Berkaitan dengan loyalitas Pelanggan, Anderson, Fornell, dan Lehmann (1994) menyatakan bahwa apabila Pelanggan puas terhadap barang atau kualitas layanan yang diberikan maka akan timbul loyalitas Pelanggan. Pelanggan yang bertahan (retained customers) memiliki peranan penting dalam persaingan bisnis yang ketat bagi pencapaian performa bisnis yang tinggi (Crane dalam Puspitasari, 2006). Sehingga strategi kualitas pelayanan yang mampu meningkatkan jumlah Pelanggan 
yang bertahan (customers retained rate) menjadi fokus utama dalam era persaingan bisnis jasa yang ketat.

Koperasi Kredit (Credit Union) disingkat dengan Kopdit CU Mandiri Cabang Medan sebagai entitas bisnis jasa yang bergerak dalam industri jasa keuangan sudah semestinya berorientasi kepada kualitas layanan dan kepuasan Pelanggan. Pelanggan yang puas merupakan salah satu aset penting untuk kelangsungan hidup dan perkembangan bisnis itu sendiri.

Fenomena yang terjadi saat ini yaitu adanya perang harga seperti biaya pendaftaran, simpanan wajib, tingkat bunga tabungan, tingkat bunga pinjaman dan sebagainya dari kopdit CU lainnya yang memperlihatkan kualitas layanannya yang lebih kompetitif. Dalam rangka meningkatkan kualitas pelayanan Kopdit CU Mandiri Tebing Tinggi telah memiliki 25 kantor cabang diberbagai daerah/kota. Dari penelitian yang telah dilakukan memberikan respon dari Pelanggan bahwa kepercayaan masyarakat terhadap pelayanan jasa Kopdit CU Mandiri yang semakin tinggi sehingga mereka merasa aman dalam menabung dan meminjam.

Brown dan Dacin (1997) membuktikan bahwa reputasi perusahaan sangat penting dari sudut pandang Pelanggan untuk memberikan gambaran terhadap kualitas produk atau jasa yang dihasilkan, dimana harga yang tinggi dari suatu merek seringkali dipersepsikan memiliki kualitas yang tinggi (Chapman dan Wahlers, 1999). Seperti dikemukakan oleh para peneliti dalam Hellier, Geursen, Carr, dan Rickard (2003) bahwa kepuasan Pelanggan secara keseluruhan pada layanan jasa berasosiasi kuat terhadap perilaku konsumen untuk menggunakan kembali jasa dari penyedia yang sama. Zeithaml (1988) mengidentifikasikan persepsi kualitas sebagai komponen dari nilai merek dimana persepsi kualitas yang tinggi akan mengarahkan konsumen untuk memilih merek tersebut dibandingkan dengan merek pesaing. Persepsi kualitas yang dirasakan oleh konsumen berpengaruh terhadap loyalitas konsumen tersebut untuk membeli sebuah produk (Chapman dan Wahlers, 1999). Oleh karena itu, masalah yang akan diteliti dirumuskan dalam bentuk pertanyaan sebagai berikut:

1. Apakah harga dan reputasi perusahaan berpengaruh positif terhadap persepsi kualitas?

2. Apakah persepsi kualitas dan kepuasan pelanggan berpengaruh positif terhadap loyalitas pelanggan ? 


\section{TINJAUAN PUSTAKA}

\section{- Pengertian Persepsi Kualitas}

Persepsi kualitas (perceived quality) dapat didefinisikan sebagai persepsi Pelanggan terhadap keseluruhan kualitas atau keunggulan suatu produk atau jasa layanan berkaitan dengan apa yang diharapkan oleh Pelanggan (Aaker, 1997). Persepsi kualitas yang tinggi menunjukkan bahwa melalui penggunaan dalam jangka waktu yang panjang, konsumen memperoleh diferensiasi dan superioritas dari merek tersebut. Zeithaml mengidentifikasikan persepsi kualitas sebagai komponen dari nilai merek dimana persepsi kualitas yang tinggi akan mengarahkan konsumen untuk memilih merek tersebut dibandingkan dengan merek pesaing. Ini berarti bahwa semakin tinggi nilai yang dirasakan oleh konsumen, maka akan semakin tinggi pula kesediaan konsumen tersebut untuk akhirnya membeli (Chapman dan Wahlers, 1999).

Persepsi kualitas mencerminkan perasaan Pelanggan yang tidak nampak dan secara menyeluruh mengenai suatu merek. Akan tetapi, biasanya persepsi kualitas didasarkan pada dimensi-dimensi yang termasuk dalam karakteristik produk tersebut dimana merek dikaitkan dengan halhal seperti keandalan dan kinerja. Lima dimensi kualitas jasa (Parasuraman, Zeithaml, dan Berry, 1988; Zeithaml et al, 1996) yang dipergunakan untuk memahami harapan dan persepsi konsumen terhadap kualitas jasa tersebut adalah :

1. Keandalan (Reliability). Kemampuan untuk melaksanakan jasa yang dijanjikan dengan tepat dan terpercaya.

2. Ketanggapan (Responsiveness). Kemauan perusahaan untuk membantu Pelanggan dan memberikan jasa dengan cepat.

3. Keyakinan (Assurance). Pengetahuan dan keramahtamahan para karyawan serta kemampuan mereka untuk menimbulkan kepercayaan dan keyakinan.

4. Empati (Empathy). Syarat untuk peduli, memberi perhatian pribadi bagi Pelanggan.

5. Berwujud (Tangibles). Penampilan fasilitas fisik (interior dan eksterior), peralatan, karyawan, dan media komunikasi.

Berdasarkan pada penelitian-penelitian tersebut diatas maka variabel persepsi kualitas dapat dibentuk dari tiga indikator, yaitu keandalan, ketanggapan, keyakinan, empati dan berujud. 
Gambar 1. Indikator-indikator Persepsi Kualitas

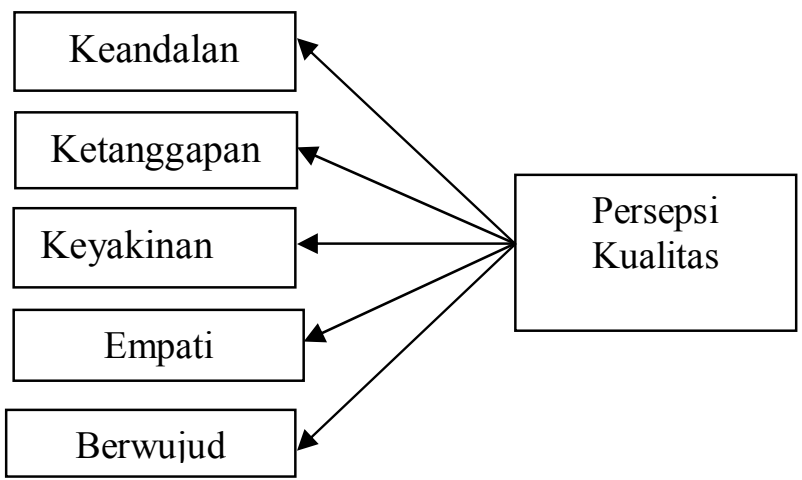

Sumber : Parasuraman et al. (1988) dan Zeithaml et al. (1996) dikembangkan dalam penelitian ini.

\section{- Kepuasan Pelanggan}

Kepuasan Pelanggan didefinisikan sebagai semua sikap berkenaan dengan barang atau jasa setelah diterima dan dipakai (Cronin \& Taylor, 1992). Cronin dan Taylor (1994) dalam penelitiannya berhasil membuktikan bahwa kepuasan Pelanggan ditentukan oleh penilaian Pelanggan terhadap kualitas pelayanan yang diberikan. Kepuasan Pelanggan menurut Spreng, Mackenzie \& Olshavsky (1996) akan dipengaruhi oleh harapan, persepsi kinerja, dan penilaian atas kinerja produk atau jasa yang dikonsumsi. Anderson, Fornell, dan Lehmann (1994); Tse dan Wilton (1988) menyatakan bahwa kepuasan atau ketidakpuasan Pelanggan adalah merupakan respon Pelanggan terhadap evaluasi ketidaksesuaian yang dirasakan antara harapan sebelumnya dan kinerja aktual produk setelah pemakaiannya. Oliver (1993) meneliti mengenai kepuasan konsumen yang menunjukkan adanya pengaruh positif antara pengalaman pembelian sebelumnya terhadap tingkat kepuasan. Berdasarkan pengalaman yang diperolehnya, Pelanggan memiliki kecenderungan untuk membangun nilainilai ekspektasi tertentu. Nilai ekspektasi tersebut akan memberikan dampak bagi Pelanggan untuk melakukan perbandingan terhadap kompetitor dari produk yang pernah dirasakannya. Berdasarkan hal-hal tersebut maka variabel kepuasan Pelanggan dapat dibentuk dari tiga indikator, yaitu kesesuaian harapan, persepsi kinerja, dan penilaian Pelanggan. 
Gambar 2. Indikator-indikator Kepuasan Pelanggan

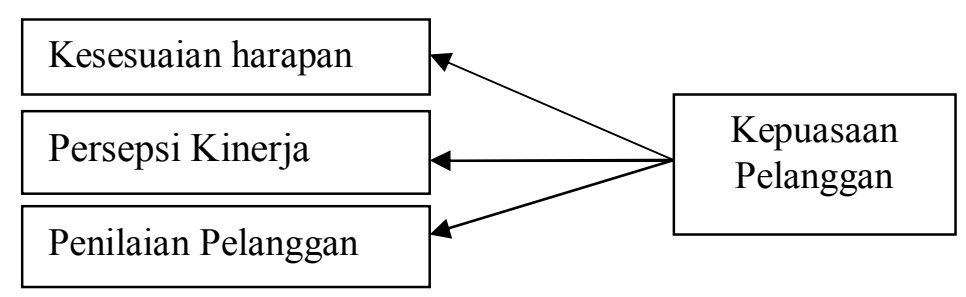

Sumber: Spreng, Mackenzie \& Olshavsky (1996) dikembangkan dalam penelitian ini

\section{- Harga}

Harga merupakan besarnya pengorbanan yang dilakukan oleh konsumen untuk memperoleh sebuah produk atau jasa yang dibutuhkan (Zeithaml, 1988). Stedman (2000) mengidentifikasikan bahwa harga merupakan salah satu factor penting yang dapat mempengaruhi perilaku konsumen dalam pembelian merek. Kennedy (1994) mengemukakan bahwa penjualan produk berkualitas tinggi kemungkinan dapat ditandai berdasarkan harga yang tinggi pula. Harga yang tinggi dapat menimbulkan persepsi kualitas produk atau jasa yang tinggi pula dari suatu merek (Monroe, 1973 dalam Ward, Chitty, and Achard, 2005; Dodds, Grewal, dan Monroe, 1991). Dalam penelitiannya, Ward, Chitty, and Achard (2005) mengukur persepsi harga dari konsumen dengan perkiraan besarnya harga yang bersedia dibayar oleh mereka untuk tiap merek terlibat. Teknik tersebut juga digunakan oleh Al-Sabbahy, Ekinci, dan Riley (2004) menilai persepsi responden terhadap kewajaran harga yang harus dibayar beradasarkan internal feeling dan pengetahuan mereka atas harga dari penyedia jasa lainnya pada bidang yang sama.

Menurut Kotler (2001) dalam membuat keputusan mengenai harga harus memperhatikan:

1. Konsumen sasaran. Apabila konsumen sasaran suatu perusahaan adalah konsumen tingkat atas maka perusahaan akan cenderung menetapkan harga yang tinggi.

2. Permintaan konsumen. Jika terjadi permintaan yang tinggi terhadap suatu produk dan jumlah barang yang tersedia sedikit maka perusahaan cenderung menetapkan harga cukup tinggi.

3. Pesaing. Jika dalam suatu pasar terdapat banyak pesaing yang menjual produk yang sejenis, produsen akan menetapkan harga yang rendah atau bersaing. 
Berdasarkan pada penelitian-penelitian tersebut diatas maka variabel harga dapat dibentuk dari tiga indikator, yaitu perkiraan harga, kesesuaian pengorbanan, dan kewajaran harga.

Gambar 3. Indikator-indikator Harga

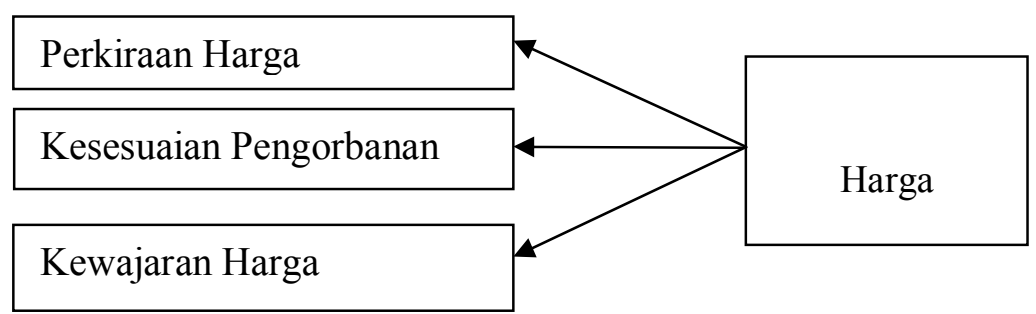

Sumber: Ward, Chitty, dan Achard (2005); Al-Sabbahy, Ekinci, dan Riley (2004); Zeithaml (1988) dikembangkan dalam penelitian ini

\section{- Reputasi Perusahaan}

Zeithaml (1988) mengemukakan bahwa kualitas yang dirasakan dari suatu produk atau jasa erat hubungannya dengan reputasi yang diasosiasikan dengan nama merek. Herbig, Milewicz dan Golden (1994) menyatakan bahwa reputasi perusahaan dapat dilihat dari kompetensi perusahaan tersebut dan keunggulan dibandingkan dengan kompetitornya. Moorman dan Minner (1997) menyatakan bahwa keberhasilan perusahaan secara maksimal dapat dicapai apabila perusahaan tersebut fokus terhadap core business, sebab hal itu akan merefleksikan core competencies yang mereka punyai. Menurut Brown dan Dacin (1997) reputasi perusahaan sangat penting dari sudut pandang Pelanggan untuk memberikan gambaran terhadap kualitas produk atau jasa yang dihasilkan. Berdasarkan pernyataan-pernyataan tersebut maka variabel reputasi perusahaan dibentuk oleh tiga indikator, yaitu pengalaman perusahaan dalam industri yang dimasukinya, kompetensi perusahaan, dan keunggulan perusahaan dibanding kompetitor. 
Gambar 4. Indikator-indikator Reputasi Perusahaan

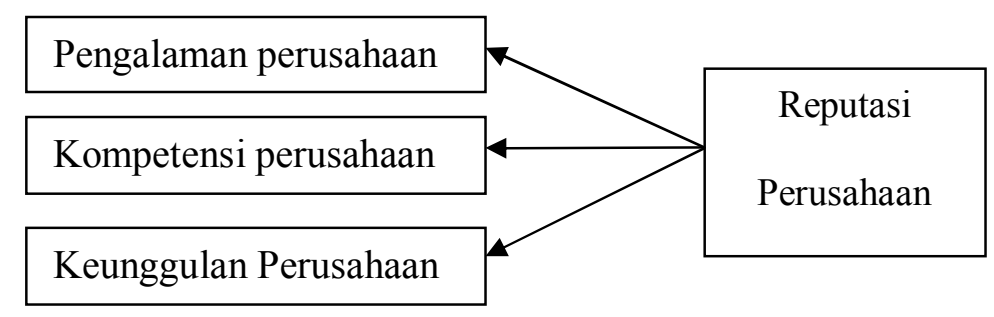

Sumber : Herbig, Milewicz dan Golden (1994); Brown dan Dacin (1997) dikembangkan dalam penelitian ini

\section{- Loyalitas Pelanggan}

Loyalitas pelanggan merupakan salah satu tujuan inti yang diupayakan dalam pemasaran modern. Karena dengan adanya loyalitas pelanggan perusahaan akan mendapatkan keuntungan dalam jangka panjang. Selanjutnya (Griffin, 2003:223) mengemukakan keuntungan-keuntungan yang akan diperoleh perusahaan apabila memiliki pelanggan yang loyal antara lain:

a. Mengurangi biaya pemasaran (karena biaya untuk menarik pelanggan baru lebih mahal)

b. Mengurangi biaya transaksi (seperti biaya negosiasi kontrak, pemrosesanpesanan, dll.)

c. Mengurangi biaya turnover pelanggan (karena pergantian pelanggan yang lebih sedikit)

d. Meningkatkan penjualan silang yang akan memperbesar pangsa pasar perusahaan.

e. Word of mouth yang lebih positif dengan asumsi bahwa pelanggan yang loyal juga berarti yang merasa puas.

Indikator dari loyalitas pelanggan (Kottler \& Keller, 2006:57) adalah Repeat Purchase (Kesetiaan terhadap pembelian produk); Retention (Ketahanan terhadap pengaruh yang negatip mengenai perusahaan); Referalls (Mereferensikan secara total eksistensi perusahaan). 
Gambar 5. Indikator-indikator Loyalitas Pelanggan

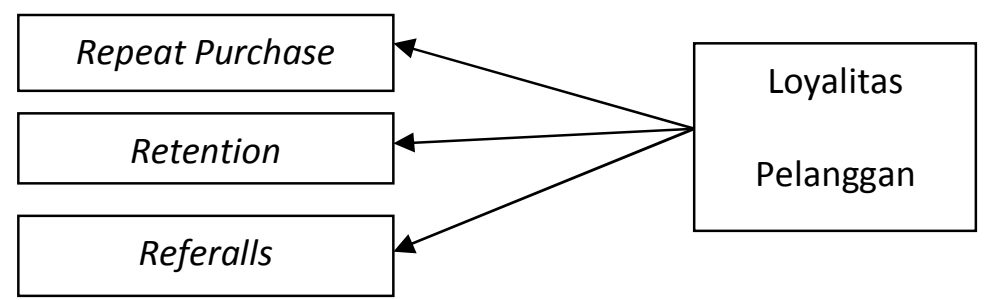

Sumber : Kottler \& Keller, 2006:57) dikembangkan dalam penelitian ini

\section{- Kerangka Pemikiran Teoritis}

Berdasarkan telaah pustaka, maka kerangka pemikiran dalam penelitian ini yaitu :

Gambar 1. Kerangka Pemikiran Teoritis

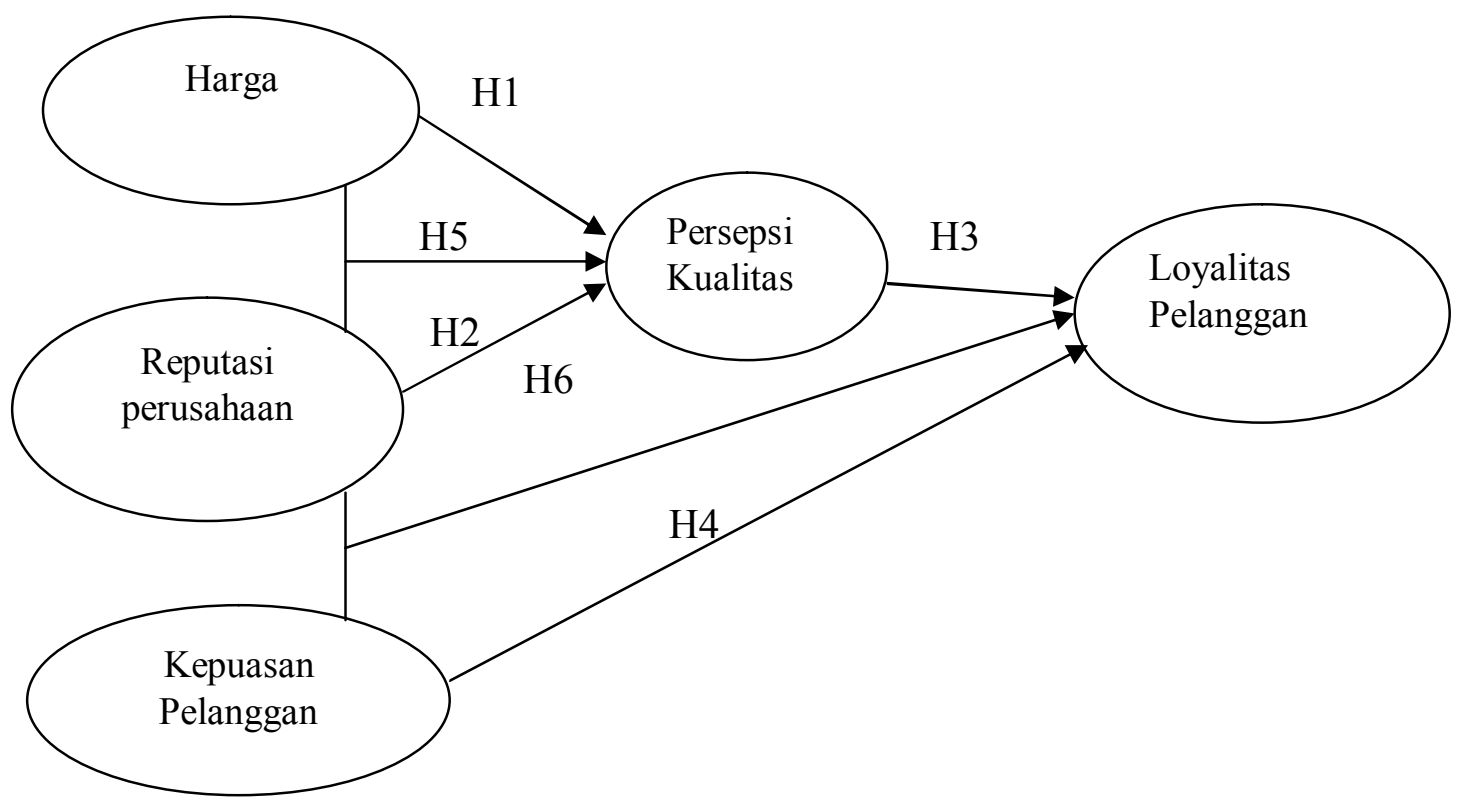

Sumber : Dikembangkan untuk penelitian ini 
Berdasarkan kerangka pemikiran di atas, maka hipotesis penelitian dapat dirumuskan :

H1 : Harga berpengaruh terhadap persepsi kualitas.

$\mathrm{H} 2$ : Reputasi perusahaan berpengaruh terhadap persepsi kualitas.

H3 : Persepsi kualitas berpengaruh terhadap loyalitas pelanggan.

H4 : Kepuasan pelanggan berpengaruh terhadap loyalitas pelanggan.

H5 : Harga dan reputasi berpengaruh perusahaan terhadap persepsi kualitas

H6 : Persepsi kualitas dan kepuasan pelanggan berpengaruh terhadap loyalitas Pelanggan.

\section{METODE PENELITIAN}

\section{- Populasi dan Sampel}

Populasi pada penelitian ini adalah seluruh Pelanggan Kopdit CU Mandiri Cabang Medan. Sampel penelitian ini sebagian dari anggota populasi. Berdasarkan tingkat keyakinan 95\% $\left(\alpha=5 \%, Z \frac{1}{2} \alpha=1,96\right)$, kesalahan maksimum $(\varepsilon)=0,1$ dan standar deviasi $(\sigma)=0,5$ maka rumus penentuan sampel (Supranto, 2001: 113):

$$
\begin{aligned}
n & =\left(\frac{Z_{\alpha / 2}^{2} \times \sigma}{\varepsilon}\right)^{2} \\
& =\left(\frac{1,96 \times 0,5}{0,1}\right)^{2} \\
& =96,04 \text { orang }
\end{aligned}
$$

Maka jumlah sampel yang dibutuhkan (n) = 96,04 dibulatkan menjadi 96 orang. Teknik penentuan sampel dilakukan secara acak sederhana.

\section{- Operasionalisasi Variabel} berikut:

Defenisi operasionalisasi variabel yang diteliti dapat dilihat pada tabel Tabel 1. Definisi Operasional Variabel

\begin{tabular}{|l|l|l|l|}
\hline Variabel & Definisi Operasional & Indikator & Pengukuran \\
\hline Harga & $\begin{array}{l}\text { Suatu pengorbanan yang } \\
\text { di persepsikan oleh } \\
\text { konsumen }\end{array}$ & $\begin{array}{l}\text { Perkiraan harga } \\
\text { Kesesuaian } \\
\text { Pengorbanan } \\
\text { Kewajaran harga }\end{array}$ & $\begin{array}{l}\text { Skala setuju - } \\
\text { tidak setuju, } \\
\text { range poin } \\
\text { penilaian 1 - 5 }\end{array}$ \\
\hline $\begin{array}{l}\text { Reputasi } \\
\text { Perusahaan }\end{array}$ & $\begin{array}{l}\text { Kepercayaan konsumen } \\
\text { atas nama baik dari }\end{array}$ & $\begin{array}{l}\text { Pengalaman } \\
\text { perusahaan }\end{array}$ & $\begin{array}{l}\text { Skala setuju - } \\
\text { tidak setuju, }\end{array}$ \\
\hline
\end{tabular}




\begin{tabular}{|l|l|l|l|}
\hline & penyedia jasa & $\begin{array}{l}\text { Kompetensi } \\
\text { perusahaan } \\
\text { Keunggulan } \\
\text { perusahaan }\end{array}$ & $\begin{array}{l}\text { range poin } \\
\text { penilaian 1 - 5 }\end{array}$ \\
\hline $\begin{array}{l}\text { Kepuasan } \\
\text { Pelanggan }\end{array}$ & $\begin{array}{l}\text { Tingkat kepuasan Yang } \\
\text { diperoleh dari } \\
\text { kemampuan penyedia } \\
\text { untuk memenuhi harapan } \\
\text { dan kebutuhan Pelanggan }\end{array}$ & $\begin{array}{l}\text { Kesesuaian harapan } \\
\text { Persepsi kinerja } \\
\text { Penilaian } \\
\text { Pelanggan }\end{array}$ & $\begin{array}{l}\text { Skala setuju - } \\
\text { tidak setuju, } \\
\text { range poin } \\
\text { penilaian 1 - 5 }\end{array}$ \\
\hline $\begin{array}{l}\text { Persepsi } \\
\text { Kualitas }\end{array}$ & $\begin{array}{l}\text { Persepsi terhadap } \\
\text { keseluruhan kualitas atau } \\
\text { keunggulan suatu produk } \\
\text { yang diharapkan oleh } \\
\text { Pelanggan }\end{array}$ & $\begin{array}{l}\text { Keandalan } \\
\text { Ketanggapan } \\
\text { Keyakinan } \\
\text { Empati } \\
\text { Berwujud }\end{array}$ & $\begin{array}{l}\text { Skala setuju - } \\
\text { tidak setuju, } \\
\text { range poin } \\
\text { penilaian 1 - 5 }\end{array}$ \\
\hline $\begin{array}{l}\text { Loyalitas } \\
\text { Pelanggan }\end{array}$ & $\begin{array}{l}\text { Kesetiaan pelanggan } \\
\text { menggunakan } \\
\text { produk/jasa yang } \\
\text { ditawarkan produsen }\end{array}$ & $\begin{array}{l}\text { Repeat Purchase } \\
\text { Retention } \\
\text { Referalls }\end{array}$ & $\begin{array}{l}\text { Skala setuju - } \\
\text { tidak setuju, } \\
\text { range poin } \\
\text { penilaian 1 - 5 }\end{array}$ \\
\hline
\end{tabular}

Sumber : Dikembangkan untuk penelitian ini

\section{- Teknik Pengumpulan Data}

Pada penelitian ini digunakan data primer melalui metode survei yang terdiri dari wawancara dan kuisioner.

\section{- Metode Analisis}

Metode analisis data yang digunakan adalah regresi linier sederhana dan berganda untuk mengetahui pengaruh variabel bebas terhadap variabel terikat (Sugiyono, 2004) dengan rumus:

$\mathrm{Y}=\beta_{0}+\beta_{1} \mathrm{X}+\varepsilon$

$Y=\beta_{0}+\beta_{1} X 1+\beta_{2} X 2+\varepsilon$

\section{Keterangan :}

$\mathrm{Y}=$ Variabel terikat, $\mathrm{X} 1$ dan $\mathrm{X} 2=$ Variabel bebas, $\beta_{0}=$ Konstanta, $\beta_{1}$ dan $\beta_{1}=$ Koefisien regresi, $\varepsilon=$ Tingkat kesalahan estimasi

Persamaan di atas diaplikasikan dalam penelitian ini dengan rumus :

$$
\begin{aligned}
& \mathrm{PK}=\beta_{0}+\beta_{1} \mathrm{H}+\varepsilon \ldots \\
& \mathrm{PK}=\beta_{0}+\beta_{1} \mathrm{RP}+\varepsilon \\
& \mathrm{LP}=\beta_{0}+\beta_{1} \mathrm{PK}+\varepsilon \\
& \mathrm{LP}=\beta_{0}+\beta_{1} \mathrm{KP}+\varepsilon
\end{aligned}
$$


$\mathrm{PK}=\beta_{0}+\beta_{1} \mathrm{H}+\beta_{2} \mathrm{RP}+\varepsilon$

$\mathrm{LP}=\beta_{0}+\beta_{1} \mathrm{KP}+\beta_{2} \mathrm{KP}+\varepsilon$

Keterangan :

PK = Persepsi Kualitas, $\mathrm{H}=$ Harga, $\mathrm{RP}=$ Reputasi Perusahaan, $\mathrm{PK}=$ Persepsi Kualitas, KP $=$ Kepuasan Pelanggan, LP = Loyalitas pelanggan, $\beta_{0}=$ Konstanta, $\beta_{1}$ dan $\beta_{2}=$ Koefisien regresi, $\varepsilon=$ Tingkat kesalahan estimasi

\section{HASIL PENELITIAN DAN PEMBAHASAN}

- Karakteristik Responden Berdasarkan Umur, Tingkat Pendidikan, dan Jenis Pejerjaan

Tabel 2. Karakteristik Responden Berdasarkan Umur

\begin{tabular}{|c|c|c|c|c|c|c|}
\hline $\begin{array}{c}\text { Umur } \\
\text { (Tahun) }\end{array}$ & $\begin{array}{c}\text { Jumlah } \\
\text { ( fi })\end{array}$ & $\begin{array}{c}\text { Tingkat } \\
\text { Pendidikan }\end{array}$ & $\begin{array}{c}\text { Jumlah } \\
\text { ( fi })\end{array}$ & $\begin{array}{c}\text { Jenis } \\
\text { Pekerjaan }\end{array}$ & $\begin{array}{c}\text { Jumlah } \\
\text { ( fi })\end{array}$ & Persentase \\
\hline $21-30$ & 17 & SMU & 35 & Pegawai & 36 & \\
\hline $31-40$ & 29 & Ahli Madya(D-3) & 30 & Swasta & 36 & \\
\hline $41-50$ & 39 & Sarjana ( S-1 ) & 26 & Wiraswasta & 50 & \\
\hline $51-60$ & 11 & Magister (S-2) & 5 & PNS & 10 & \\
\hline Jumlah & 96 & Jumlah & 96 & Jumlah & 96 & 100 \\
\hline
\end{tabular}

Sumber : Diolah dari hasil koesioner

Tabel di atas menunjukkan, nasabah Koperasi Kredit (Credit Union) Mandiri Cabang Medan lebih dominan yang berumur 41 - 50 tahun kemudian 31 - 40 tahun. Untuk tingkat pendidikan dominan tingkat pendidikan SMU dan Ahli Madya (D3). Sedangkan untuk perkerjaan, nasabah Koperasi Kredit (Credit Union) Mandiri Cabang Medan lebih dominan jenis pekerjaannya wiraswasta dan Pegawai Swasta.

- Persamaan - Persamaan Regresi Variabel Penelitian Pengaruh Variabel Harga Terhadap Persepsi Kualitas

Hasil pengolahan data tentang pengaruh Harga terhadap persepsi kualitas: 
Tabel 5. Coefficients ${ }^{\mathrm{a}}$ Regresi Linier Harga Terhadap Persepsi Kualitas

\begin{tabular}{|c|c|c|c|c|c|}
\hline \multirow[b]{2}{*}{ Model } & \multicolumn{2}{|c|}{$\begin{array}{c}\text { Unstandardized } \\
\text { Coefficients }\end{array}$} & $\begin{array}{l}\text { Standardized } \\
\text { Coefficients }\end{array}$ & \multirow[b]{2}{*}{$\mathrm{t}$} & \multirow[b]{2}{*}{ Sig. } \\
\hline & B & Std. Error & Beta & & \\
\hline (Constant) & 3.324 & .772 & & 4.306 & .000 \\
\hline Harga & .755 & .057 & .755 & 13.290 & .000 \\
\hline
\end{tabular}

a. Dependent Variable: Persepsi Kualitas $(Y)$

b. Independent Variable: Harga ( $X$ )

Persamaan regresi tabel di atas: $\mathrm{Y}=3,324+0,755 \mathrm{X}$. Persamaan tersebut menunjukkan bahwa variabel harga mempunyai pengaruh yang positif terhadap persepsi kualitas.

Tabel 6. Koefisien Korelasi dan Determinasi Harga Terhadap Persepsi Kualitas

\begin{tabular}{|c|c|c|c|c|}
\hline & & & & \\
Model & $\mathrm{R}$ & R Square & $\begin{array}{c}\text { Adjusted R } \\
\text { Square }\end{array}$ & Std. Error of the Estimate \\
\hline 1 & $.755^{\mathrm{a}}$ & .570 & .567 & .731 \\
\hline
\end{tabular}

a. Predictors: (Constant), Harga

Tabel 7. F. Hitung Harga Terhadap Persepsi Kualitas

\begin{tabular}{|cl|c|c|c|c|c|}
\hline \multicolumn{1}{|c|}{ Model } & $\begin{array}{c}\text { Sum of } \\
\text { Squares }\end{array}$ & $\mathrm{df}$ & Mean Square & $\mathrm{F}$ & Sig. \\
\hline 1 & Regression & 94.374 & 1 & 94.374 & 176.627 & $.000^{\mathrm{a}}$ \\
& Residual & 71.063 & 133 & .534 & & \\
& Total & 165.437 & 134 & & & \\
\hline
\end{tabular}

a. Predictors: (Constant), Harga b. Dependent Variable: Persepsi Kualitas Sumber : Hasil pengolahan data SPSS Versi 17 
Tabel di atas, menunjukkan nilai $\mathrm{t}$ hitung $>\mathrm{t}$ tabel dan $\mathrm{F}$ hitung $>\mathrm{F}$ tabel. Hal ini berarti, variabel harga mempunyai pengaruh yang signifikan terhadap persepsi kualitas dengan signifikansi 0,000.

\section{Pengaruh Variabel Reputasi Perusahaan Terhadap Persepsi Kualitas}

Hasil pengolahan data pengaruh Reputasi Perusahaan terhadap persepsi kualitas:

Tabel 8. Coefficients ${ }^{\mathrm{a}}$ Regresi Linier Reputasi Perusahaan Terhadap Persepsi Kualitas

\begin{tabular}{|cl|c|c|c|c|c|}
\hline & & \multicolumn{2}{|c|}{$\begin{array}{c}\text { Unstandardized } \\
\text { Coefficients }\end{array}$} & $\begin{array}{c}\text { Standardized } \\
\text { Coefficients }\end{array}$ & & \\
\cline { 3 - 5 } & Model & $\mathrm{B}$ & Std. Error & Beta & $\mathrm{t}$ & Sig. \\
\hline \multirow{2}{*}{1} & (Constant) & 3.217 & .757 & & 4.249 & .000 \\
& Reputasi Perusahaan & .764 & .056 & .765 & 13.690 & .000 \\
\hline
\end{tabular}

a. Dependent Variable: Persepsi Kualitas( Y )

b. Independent Variable: Reputasi Perusahaan ( X )

Persamaan regresinya adalah: $\mathrm{Y}=3,217+0,764 \mathrm{X}$. Hal ini menunjukkan bahwa variabel reputasi perusahaan mempunyai pengaruh yang positif terhadap persepsi kualitas.

Tabel 9. Koefisien Korelasi dan Determinasi Variabel Reputasi Perusahaan Terhadap Persepsi Kualitas

\begin{tabular}{|c|c|c|c|c|}
\hline & & & & \\
Model & $\mathrm{R}$ & $\mathrm{R}$ Square & Adjusted R Square & $\begin{array}{c}\text { Std. Error of the } \\
\text { Estimate }\end{array}$ \\
\hline 1 & $.765^{\mathrm{a}}$ & .585 & .582 & .719 \\
\hline
\end{tabular}

a. Predictors: (Constant), Reputasi Perusahaan

Tabel di atas menunjukkan koefisien korelasi variabel reputasi perusahaan dengan persepsi kualitas sangat kuat dengan nilai $r=0,765$. Koefisien determinasinya sebesar $r^{2}=0,585$, artinya variabel reputasi perusahaan mampu menjelaskan 58,5\% terhadap persepsi kualitas, sedangkan 41,5\% dipengaruhi oleh faktor-faktor lain. 
Tabel 10. F. Hitung Variabel Reputasi Perusahaan Terhadap Persepsi Kualitas

\begin{tabular}{|ll|c|c|c|c|c|}
\hline Model & & Sum of Squares & df & Mean Square & F & Sig. \\
\hline 1 & Regression & 96.769 & 1 & 96.769 & 187.430 & $.000^{\mathrm{a}}$ \\
& Residual & 68.668 & 133 & .516 & & \\
& Total & 165.437 & 134 & & & \\
\hline
\end{tabular}

a. Predictors: (Constant), Reputasi Perusahaan

b. Dependent Variable: Persepsi Kualitas

Sumber : Hasil pengolahan data SPSS Versi 17

Tabel di atas, menunjukkan nilai $\mathrm{t}$ hitung $>\mathrm{t}$ tabel dan $\mathrm{F}$ hitung $>\mathrm{F}$ tabel dari variabel reputasi perusahaan. Hal ini berarti, variabel reputasi perusahaan mempunyai pengaruh yang signifikan terhadap persepsi kualitas dengan signifikansi 0,000.

\section{Pengaruh Variabel Persepsi Kualitas Terhadap Variabel Minat Pembelian Ulang}

Hasil pengolahan data pengaruh Persepsi Kualitas Terhadap Minat Pembelian Ulang:

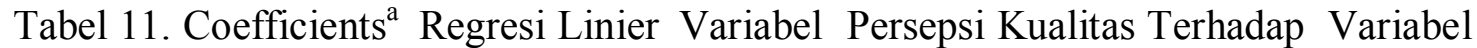
Minat Pembelian Ulang

\begin{tabular}{|ll|c|c|c|c|c|}
\hline \multirow{2}{*}{ Model } & \multicolumn{2}{|c|}{$\begin{array}{c}\text { Unstandardized } \\
\text { Coefficients }\end{array}$} & $\begin{array}{c}\text { Standardized } \\
\text { Coefficients }\end{array}$ & \multirow{2}{*}{ S } \\
\cline { 2 - 5 } & $\mathrm{B}$ & Std. Error & Beta & $\mathrm{t}$ & Sig. \\
\hline 1 & (Constant) & 3.788 & .855 & & 4.431 & .000 \\
& Persepsi Kualitas & .716 & .063 & .702 & 11.378 & .000 \\
\hline
\end{tabular}

a. Dependent Variable: Minat Pembelian Ulang ( Y )

b. Independent Variable: Persepsi Kualitas ( X)

Persamaan regresi nya dalah: $\mathrm{Y}=3,788+0,716 \mathrm{X}$. Persamaan tersebut menunjukkan bahwa persepsi kualitas mempunyai pengaruh yang positif terhadap minat pembelian ulang. 
Tabel 12. Koefisien Korelasi dan Determinasi Variabel Persepsi Kualitas Terhadap Variabel Minat Pembelian Ulang

\begin{tabular}{|c|c|c|c|c|}
\hline & & & & \\
Model & $\mathrm{R}$ & $\mathrm{R}$ Square & $\begin{array}{c}\text { Adjusted R } \\
\text { Square }\end{array}$ & $\begin{array}{c}\text { Std. Error of the } \\
\text { Estimate }\end{array}$ \\
\hline 1 & $.702^{\mathrm{a}}$ & .493 & .489 & .809 \\
\hline
\end{tabular}

a. Predictors: (Constant), Persepsi Kualitas

Tabel di atas menunjukkan koefisien korelasi variabel persepsi kualitas dengan minat pembelian ulang sangat kuat dengan nilai $r=0,702$. Koefisien determinasinya sebesar $r^{2}=0,493$, artinya variabel persepsi kualitas mampu menjelaskan 49,3\% terhadap minat pembelian ulang, sedangkan 50,7 \% dipengaruhi oleh faktor-faktor lain.

Tabel 13. F. Hitung Variabel Persepsi Kualitas Terhadap Variabel Minat Pembelian Ulang

\begin{tabular}{|ll|c|c|c|c|c|}
\hline \multicolumn{2}{|l|}{ Model } & Sum of Squares & $\mathrm{df}$ & Mean Square & $\mathrm{F}$ & Sig. \\
\hline 1 & Regression & 84.694 & 1 & 84.694 & 129.461 & $.000^{\mathrm{a}}$ \\
& Residual & 87.010 & 133 & .654 & & \\
Total & 171.704 & 134 & & & \\
\hline
\end{tabular}

a. Predictors: (Constant), Persepsi Kualitas

b. Dependent Variable: Minat Pembelian Ulang

Sumber : Hasil pengolahan data SPSS Versi 17

Tabel di atas, menunjukkan nilai $\mathrm{t}$ hitung $>\mathrm{t}$ tabel dan $\mathrm{F}$ hitung $>\mathrm{F}$ tabel dari variabel persepsi kualitas. Hal ini berarti, variabel persepsi kualitas mempunyai pengaruh yang signifikan terhadap minat pembelian ulang dengan signifikansi 0,000 .

\section{Pengaruh Variabel Kepuasan Pelanggan Terhadap Variabel Minat Pembelian Ulang}

Hasil pengolahan data pengaruh Kepuasan Pelanggan Terhadap Minat Pembelian Ulang: 
Tabel 14. Coefficients ${ }^{\mathrm{a}}$ Regresi Linier Variabel Kepuasan Pelanggan Terhadap Variabel Minat Pembelian Ulang

\begin{tabular}{|c|c|c|c|c|c|c|}
\hline \multirow{2}{*}{\multicolumn{2}{|c|}{ Model }} & \multicolumn{2}{|c|}{$\begin{array}{l}\text { Unstandardized } \\
\text { Coefficients }\end{array}$} & $\begin{array}{l}\text { Standardized } \\
\text { Coefficients }\end{array}$ & \multirow[b]{2}{*}{$\mathrm{t}$} & \multirow[b]{2}{*}{ Sig. } \\
\hline & & B & Std. Error & Beta & & \\
\hline 1 & (Constant) & 4.655 & .889 & & 5.236 & .000 \\
\hline & $\begin{array}{l}\text { Kepuasan } \\
\text { Pelanggan }\end{array}$ & .654 & .066 & .654 & 9.962 & .000 \\
\hline
\end{tabular}

a. Dependent Variable: Minat Pembelian Ulang ( Y )

b. Independent Variable: Kepuasan Pelanggan ( $\mathrm{X}$ )

Persamaan regresi nya adalah: $\mathrm{Y}=4,655+0,654 \mathrm{X}$. Persamaan tersebut menunjukkan bahwa kepuasan pelanggan mempunyai pengaruh yang positif terhadap minat pembelian ulang.

Tabel 15. Koefisien Korelasi dan Determinasi Variabel Kepuasan Pelanggan Terhadap Variabel Minat Pembelian Ulang

\begin{tabular}{|c|c|c|c|c|}
\hline & & & & \\
Model & $\mathrm{R}$ & R Square & $\begin{array}{c}\text { Adjusted R } \\
\text { Square }\end{array}$ & $\begin{array}{c}\text { Std. Error of } \\
\text { the Estimate }\end{array}$ \\
\hline 1 & $.654^{\mathrm{a}}$ & .427 & .423 & .860 \\
\hline
\end{tabular}

a. Predictors: (Constant), Kepuasan Pelanggan

Tabel di atas menunjukkan koefisien korelasi variabel kepuasan pelanggan dengan minat pembelian ulang yang kuat dengan nilai $r=0,654$. Koefisien determinasinya sebesar $r^{2}=0,42,7$, artinya variabel kepuasan pelanggan mampu menjelaskan $42,7 \%$ terhadap minat pembelian ulang, sedangkan $57,3 \%$ dipengaruhi oleh faktor-faktor lain. 
Tabel 16. F. Hitung Variabel Kepuasan Pelanggan Terhadap Variabel Minat Pembelian Ulang

\begin{tabular}{|ll|c|c|c|c|c|}
\hline \multicolumn{2}{|l|}{ Model } & Sum of Squares & $\mathrm{df}$ & Mean Square & $\mathrm{F}$ & Sig. \\
\hline 1 & Regression & 73.376 & 1 & 73.376 & 99.249 & $.000^{\mathrm{a}}$ \\
& Residual & 98.328 & 133 & .739 & & \\
Total & 171.704 & 134 & & & \\
\hline
\end{tabular}

a. Predictors: (Constant), Kepuasan Pelanggan

b. Dependent Variable: Minat Pembelian Ulang

Tabel di atas, menunjukkan nilai $\mathrm{t}$ hitung $>\mathrm{t}$ tabel dan $\mathrm{F}$ hitung $>\mathrm{F}$ tabel dari kepuasan pelanggan. Hal ini berarti, kepuasan pelanggan mempunyai pengaruh yang signifikan terhadap minat pembelian ulang dengan signifikansi 0,000 .

\section{Pengaruh Harga dan Reputasi Perusahaan Terhadap Persepsi Kualitas}

Hasil pengolahan data pengaruh Harga dan Reputasi Perusahaan Terhadap Persepsi Kualitas sebagai berikut :

Tabel 17. Coefficients ${ }^{\mathrm{a}}$ Regresi Berganda Variabel Harga dan Reputasi Perusahaan Terhadap Variabel Persepsi Kualitas

\begin{tabular}{|c|c|c|c|c|c|c|}
\hline \multirow{2}{*}{\multicolumn{2}{|c|}{ Model }} & \multicolumn{2}{|c|}{$\begin{array}{c}\text { Unstandardized } \\
\text { Coefficients }\end{array}$} & \multirow{2}{*}{$\frac{\begin{array}{c}\text { Standardized } \\
\text { Coefficients }\end{array}}{\text { Beta }}$} & \multirow[b]{2}{*}{$\mathrm{t}$} & \multirow[b]{2}{*}{ Sig. } \\
\hline & & B & Std. Error & & & \\
\hline 1 & (Constant) & 3.069 & .763 & & 4.021 & .000 \\
\hline & $\operatorname{Harga}(X 1)$ & .266 & .201 & .266 & 1.319 & .189 \\
\hline & $\begin{array}{l}\text { Reputasi } \\
\text { Perusahaan(X2) }\end{array}$ & .509 & .201 & .510 & 2.531 & .013 \\
\hline
\end{tabular}

a. Dependent Variable: Persepsi Kualitas

Persamaan regresi nya : $Y=3,069+0,266 X 1+0,509 X 2$. Persamaan tersebut menunjukkan bahwa harga dan reputasi perusahaan mempunyai pengaruh yang positif terhadap persepsi kualitas. 
Tabel 18. Koefisien Korelasi dan Determinasi Variabel Harga dan Reputasi Perusahaan Terhadap Variabel Persepsi Kualitas

\begin{tabular}{|c|c|c|c|c|}
\hline Model & $\mathrm{R}$ & R Square & Adjusted R Square & $\begin{array}{c}\text { Std. Error of the } \\
\text { Estimate }\end{array}$ \\
\hline 1 & $.768^{\mathrm{a}}$ & .590 & .584 & .717 \\
\hline
\end{tabular}

a. Predictors: (Constant), Reputasi Perusahaan, Harga

Tabel di atas menunjukkan koefisien korelasi variabel harga dan reputasi perusahaan terhadap persepsi kualitas yang sangat kuat dengan nilai $\mathrm{r}=$ 0,768 . Koefisien determinasinya sebesar $r^{2}=0,590$, artinya variabel Harga dan reputasi perusahaan mampu menjelaskan $59 \%$ terhadap persepsi kualitas, sedangkan $41 \%$ dipengaruhi oleh faktor-faktor lain.

Tabel 19. F. Hitung Variabel Harga dan Reputasi Perusahaan Terhadap Variabel Persepsi Kualitas

\begin{tabular}{|c|c|c|c|c|c|c|}
\hline & Model & Sum of Squares & Df & Mean Square & F & Sig. \\
\hline 1 & Regression & 97.663 & 2 & 48.832 & 95.107 & $.000^{\text {a }}$ \\
& Residual & 67.774 & 132 & .513 & & \\
& Total & 165.437 & 134 & & & \\
\hline
\end{tabular}

a. Predictors: (Constant), Reputasi Perusahaan, Harga

b. Dependent Variable: Persepsi Kualitas

Tabel di atas, menunjukkan nilai $\mathrm{t}$ hitung $>\mathrm{t}$ tabel dan $\mathrm{F}$ hitung $>\mathrm{F}$ tabel dari variabel harga dan reputasi perusahaan. Hal ini berarti, variabel harga dan reputasi perusahaan mempunyai pengaruh yang signifikan secara parsial dan simultan terhadap persepsi kualitas dengan signifikansi 0,000.

\section{Pengaruh Variabel Persepsi Kualitas dan Kepuasan Pelanggan Terhadap Variabel Minat Pembelian Ulang}

Hasil pengolahan data pengaruh persepsi kualitas dan kepuasan pelanggan terhadap variabel minat pembelian ulang sebagai berikut : 
Tabel 20. Coefficients ${ }^{\mathrm{a}}$ Regresi Berganda Variabel Persepsi Kualitas dan Kepuasan Pelanggan Terhadap Variabel Minat Pembelian Ulang

\begin{tabular}{|l|c|c|c|c|c|}
\hline \multirow{2}{*}{\multicolumn{1}{|c|}{ Model }} & \multicolumn{2}{|c|}{$\begin{array}{c}\text { Unstandardized } \\
\text { Coefficients }\end{array}$} & $\begin{array}{c}\text { Standardized } \\
\text { Coefficients }\end{array}$ & & \\
\cline { 2 - 4 } & $\mathrm{B}$ & Std. Error & Beta & $\mathrm{t}$ & Sig. \\
\hline 1 (Constant) & 3.556 & .871 & & 4.081 & .000 \\
Persepsi Kualitas (X1) & .568 & .130 & .558 & 4.364 & .000 \\
Kepuasan Pelanggan (X2) & .165 & .128 & .165 & 1.288 & .200 \\
\hline
\end{tabular}

a. Dependent Variable: Minat Pembelian Ulang

Tabel di atas, menunjukkan persamaan regresi : $\mathrm{Y}=3,556+0,568 \mathrm{X} 1+$ $0,165 X 2$. Persamaan tersebut menunjukkan bahwa variabel persepsi kualitas dan kepuasan pelanggan mempunyai pengaruh yang positif terhadap minat pembelian ulang.

Tabel 21. Koefisien Korelasi dan Determinasi Variabel Persepsi Kualitas dan Kepuasan Pelanggan Terhadap Variabel Minat Pembelian Ulang

\begin{tabular}{|c|c|c|c|c|}
\hline & & & & \\
Model & $\mathrm{R}$ & $\mathrm{R}$ Square & Adjusted R Square & $\begin{array}{c}\text { Std. Error of the } \\
\text { Estimate }\end{array}$ \\
\hline 1 & $.707^{\mathrm{a}}$ & .500 & .492 & .807 \\
\hline
\end{tabular}

a. Predictors: (Constant), Kepuasan Pelanggan, Persepsi Kualitas

Tabel di atas menunjukkan koefisien korelasi variabel kepuasan pelanggan dan persepsi kualitas terhadap minat pembelian ulang sangat kuat dengan nilai $r=0,707$. Koefisien determinasinya sebesar $r^{2}=0,50$, artinya variabel kepuasan pelanggan dan persepsi kualitas mampu menjelaskan 50 $\%$ terhadap minat pembelian ulang, sedangkan $50 \%$ dipengaruhi oleh faktor-faktor lain. 
Tabel 22. F. Hitung Variabel Persepsi Kualitas dan Kepuasan Pelanggan Terhadap Variabel Minat Pembelian Ulang

\begin{tabular}{|cl|c|c|c|c|c|}
\hline \multicolumn{1}{|c|}{ Model } & Sum of Squares & $\mathrm{df}$ & Mean Square & $\mathrm{F}$ & Sig. \\
\hline & Regression & 85.775 & 2 & 42.887 & 65.882 & $.000^{\mathrm{a}}$ \\
& Residual & 85.929 & 132 & .651 & & \\
& Total & 171.704 & 134 & & & \\
\hline
\end{tabular}

a. Predictors: (Constant), Kepuasan Pelanggan, Persepsi Kualitas

b. Dependent Variable: Minat Pembelian Ulang

Tabel di atas, menunjukkan nilai $\mathrm{t}$ hitung $>\mathrm{t}$ tabel dan $\mathrm{F}$ hitung $>\mathrm{F}$ tabel dari variabel kepuasan pelanggan dan persepsi Kualitas. Hal ini berarti, variabel kepuasan pelanggan dan persepsi kualitas mempunyai pengaruh yang signifikan secara parsial dan simultan terhadap minat pembelian ulang dengan signifikansi 0,000 .

Hasil penelitian menunjukkan bahwa pengaruh Variabel Harga Terhadap Persepsi Kualitas menunjukkan pengaruh yang positif dan signifikan. Hal ini sejalan dengan hasil penelitian sebelumnya yang mengemukakan bahwa harga yang tinggi dari suatu merek seringkali dipersepsikan memiliki kualitas yang tinggi dan tidak peka terhadap persaingan potongan harga seperti merek-merek dengan harga yang rendah (Yoo, Donthu, dan Lee, 2000). Pada penelitiannya, Rao dan Monroe (1989) menyatakan bahwa harga berkorelasi positif terhadap persepsi kualitas. Sedangkan Chapman dan Wahlers (1999) menyatakan bahwa semakin meningkat harga maka persespsi konsumen terhadap kualitas juga semakin meningkat. Oleh karena itu, harga yang tinggi berperan sebagai sinyal terhadap kualitas suatu produk. Maka hipotesis yang diajukan dapat diterima.

Hasil penelitian menunjukkan bahwa pengaruh Variabel Reputasi Perusahaan Terhadap Persepsi Kualitas menunjukkan pengaruh yang positif dan signifikan. Hal ini sejalan dengan hasil penelitian sebelumnya Zeithaml (1988) mengemukakan bahwa kualitas yang dirasakan (perceived quality) dari suatu produk atau jasa erat hubungannya dengan reputasi yang diasosiasikan dengan nama merek. Reputasi perusahaan sangat penting dari sudut pandang pelanggan untuk memberikan gambaran terhadap kualitas produk atau jasa yang dihasilkan (Brown dan Dacin, 1997). Herbig, Milewicz dan Golden (1994) menyatakan bahwa reputasi perusahaan dapat dilihat dari kompetensi perusahaan tersebut dan 
keunggulan dibandingkan dengan kompetitornya. Maka hipotesis yang diajukan dapat diterima.

Hasil penelitian menunjukkan bahwa pengaruh Variabel Persepsi Kualitas Terhadap Variabel Minat Pembelian Ulang menunjukkan pengaruh yang positif dan signifikan. Hal ini sejalan dengan hasil penelitian sebelumnya Persepsi kualitas jasa dengan lima dimensi kualitas jasa berhubungan positif terhadap minat beli ulang pelanggan (Li dan Lee, 2001). Parasuraman, Zeithaml, dan Berry (1985, 1988) mengemukakan bahwa terdapat hubungan secara langsung antara persepsi kualitas dengan minat beli ulang. Persepsi kualitas yang dirasakan oleh konsumen akan berpengaruh terhadap kesediaan konsumen tersebut untuk membeli sebuah produk. Ini berarti bahwa semakin tinggi nilai yang dirasakan oleh konsumen, maka akan semakin tinggi pula kesediaan konsumen tersebut untuk akhirnya membeli (Chapman dan Wahlers, 1999). Menurut Dodds (1991) minat membeli dipengaruhi oleh nilai dari produk yang dievaluasi. Dengan adanya persepsi kualitas yang tinggi maka pelanggan akan memiliki minat untuk menggunakan kembali jasa dari provider yang sama (Li dan Lee, 2001). Maka hipotesis yang diajukan dapat diterima.

Hasil penelitian menunjukkan bahwa pengaruh Variabel Kepuasan Pelanggan yang positif terhadap variabel Minat Pembelian Ulang menunjukkan pengaruh yang positif dan signifikan. Hal ini sejalan dengan hasil penelitian sebelumnya bahwa kepuasan pelanggan penting bagi para pemasar karena merupakan determinan dari pembelian ulang (Bearden dan Teel, 1983 dalam Woodside, Frey, dan Daly, 1989). Terdapat hubungan positif secara langsung antara kepuasan pelanggan dengan minat beli ulang yang didukung oleh hasil-hasil penelitian terhadap berbagai kategori produk dan jasa (Anderson dan Sullivan, 1993; Rust dan Zahorik, 1993; Selnes, 1998; Swan dan Trawick, 1981; Taylor dan Baker, 1994; Woodside et al, 1989 dalam Hellier, Geursen, Carr, dan Rickard, 2003). Dengan adanya kepuasan dari pelanggan, maka pelanggan akan memiliki minat untuk menggunakan kembali jasa dari provider yang sama (Hellier, Geursen, Carr, dan Rickard, 2002; Cronin dan Taylor, 1992). Maka hipotesis yang diajukan dapat diterima. 


\section{KESIMPULAN}

Berdasarkan hasil penelitian dan pembahasan terdapat beberapa kesimpulan :

1. Harga mempunyai pengaruh yang positif dan signifikan terhadap Persepsi Kualitas. Hal ini didukung hasil penelitian Yoo, Donthu, dan Lee, 2000 yang mengemukakan bahwa harga yang tinggi dari suatu merek seringkali dipersepsikan memiliki kualitas yang tinggi. Demikian juga dukungan penelitian Rao dan Monroe (1989) menyatakan bahwa harga berkorelasi positif terhadap persepsi kualitas. Maka hipotesis yang diajukan dapat diterima.

2. Reputasi Perusahaan mempunyai pengaruh yang positif dan signifikan terhadap Persepsi Kualitas. Hal ini sejalan dengan hasil penelitian Zeithaml (1988), mengemukakan bahwa kualitas yang dirasakan (perceived quality) erat hubungannya dengan reputasi yang diasosiasikan dengan nama merek. Herbig, Milewicz dan Golden (1994) menyatakan, reputasi perusahaan dapat dilihat dari kompetensi perusahaan dan keunggulan dibandingkan dengan kompetitornya. Maka hipotesis yang diajukan dapat diterima.

3. Persepsi Kualitas berpengaruh positif dan signifikan terhadap Variabel Minat Pembelian Ulang. Hal ini sejalan dengan hasil penelitian sebelumnya Persepsi kualitas jasa dengan lima dimensi kualitas jasa berhubungan positif terhadap minat beli ulang pelanggan ( $\mathrm{Li}$ dan Lee, 2001). Parasuraman, Zeithaml, dan Berry $(1985$, 1988) berpendapat terdapat hubungan secara langsung antara persepsi kualitas dengan minat beli ulang. Maka hipotesis diterima.

4. Kepuasan Pelanggan mempunyai pengaruh yang positif dan signifikan terhadap variabel Minat Pembelian Ulang. Hal ini sejalan dengan hasil penelitian bahwa kepuasan pelanggan merupakan determinan dari pembelian ulang (Bearden dan Teel, 1983 dalam Woodside, Frey, dan Daly, 1989). Dengan adanya kepuasan dari pelanggan, maka pelanggan akan memiliki minat untuk menggunakan kembali jasa dari provider yang sama (Hellier, Geursen, Carr, dan Rickard, 2002; Cronin dan Taylor, 1992). Maka hipotesis yang diajukan dapat diterima 


\section{DAFTAR PUSTAKA}

Aaker, David A. (1997), Should You Take Your Brand to Where the action is, Harvard Business Review, Vol. 75, Sept/Oct, p.135-143.

Anderson, Eugene W., Claes Fornell, dan Donald R. Lehmann (1994), "Customer Satisfaction, Market Share, and Profitabiliy : Finding from Sweden", Journal of Marketing, Vol. 58, p.53-66.

Chapman, Joe dan Russ Wahlers (1999), "A Revision and Empirical Test of the Extended Price-Perceived Quality Model", Journal of Marketing, p.53- 64.

Cobb-Walgren, Cathy, Cynthia A. Ruble, dan Naveen Donthu (1995), "Brand Equity, Brand Preference and Purchase Intent", Journal of Advertising, 24 (3), p.25-40.

Diana Puspitasari 2006, Analisis Pengaruh Persepsi Kualitas dan Kepuasan Pelanggan Terhadap Minat Beli Ulang (Studi Kasus pada Maskapai Penerbangan Garuda Keberangkatan Semarang), Program Pasca Sarjana Universitas Diponegoro Semarang

Fornell, Claes (1992), "A National Customer Satisfaction Barometer : The Swedish Experience", Journal of Marketing, Vol. 56, Jan, p.6-21.

Hawkins, Del I., Roger J. Best, dan Kenneth A. Coney (1998), Consumer Behavior :Building Marketing Strategy, Irwin/McGraw-Hill.

Hellier, Phillip K., Gus M. Geursen, Rodney A. Carr, dan John A. Rickard (2003), "Customer Repurchase Intention : A General Structural Equation Model", European Journal of Marketing, Vol. 37/11, p.1762-1800.

Kotler, Philip dan Armstrong, Gary, 2001. Prinsip-prinsip Pemasaran, Jilid 1, Alih Bahasa: Damos Sihombing, Edisi Kedelapan, Jakarta : Erlangga.

Li, Chieh-Lu dan Joohyun Lee (2001), "Dimensions of Service and Their Influence on Intention to Repurchase", Department of Leisure Studies Penn State University.

Parasuraman, A., Valerie A. Zeithaml, dan Leonard L. Berry (1988), “A Multiple Item Scale for Measuring Consumer Perception on Future Research", Journal of Marketing, Vol. 49/1.

Söderlund, Magnus dan Mats Vilgon (1999), "Customer Satisfaction and Links to Customer Profitability : an Empirical Examination of the Association Between Attitudes and Behavior", Working Paper Series in Business Administration, No. 1. 
Sugiyono, 2004. Metode Penelitian Bisnis, Cetakan Keenam, Bandung: Alfabeta.

Ward, Steven, William Chitty, dan Brendan Achard (2005), "Brand Equity in an Online World", Journal of Internet Business, Vol. 2 (April).

Zeithaml, V. A. (1988), "Consumer Perceptions of Price, Quality, and Value : A Means-End Model and Synthesis of Evidence", Journal of Marketing, Vol. 52, July, p.52-54.

Zeithaml, V. A. dan Mario Jo Bitner (1996), Service Marketing, McGrawHill Companies Inc., New York.

Staff.uny.ac.id/sites/default/files/pendidikan/Dra. Endang Mulyatiningsih, M.Pd./Metode Penentuan Sampel.pdf 